\title{
Proceeding
}

Supplementary Issue: Summer Conferences of Sports Science. Costa Blanca Sports Science Events, 25-26 September 2020. Alicante, Spain.

\section{Circus-mobility: The value of a circus laboratory at school}

\author{
MANUELA VALENTINI ${ }^{1} \Delta$, ALICE CESAURI $^{1}$, ROSARIA SCHEMBRI ${ }^{2}$, ARIO FEDERICI ${ }^{1}$ \\ 1 University of Urbino Carlo Bo, Italy \\ 2University of Enna Kore, Italy
}

\begin{abstract}
The circus has always fascinated children due to its magic, imaginary and creativity. In this work, we analyse international research which emphasises the value of the discipline of the circus in relation to mobility. The aim of the study is to introduce the circus into schools. Although there is no unique definition of circus pedagogy as yet, scholars agree that such a discipline could provide a valid alternative to learn and deepen various mobility contents. We report examples of proposed school activities from the international landscape. Taking into consideration that circus pedagogy is little known in Italy, a comparison with the "National curriculum guidelines for 2012" Italy, was key to adapting this discipline to the Italian school context (in nursery and primary school) contributing to create and integrate a pupil's mobility experience creatively.

Keywords: Physic education; Circus; Social circus; Motor skills; Circus psychomotor skills; Circus pedagogy.

\section{Cite this article as:}

Valentini, M., Cesauri, A., Schembri, R., \& Federici, A. (2020). Circus-mobility: The value of a circus laboratory at school. Journal of Human Sport and Exercise, 15(4proc), S1081-S1092. doi:https://doi.org/10.14198/ihse.2020.15.Proc4.10
\end{abstract}

Corresponding author. University of Urbino Carlo Bo, Italy.

E-mail: manuela.valentini@uniurb.it

Abstract submitted to: Spring Conferences of Sports Science. Costa Blanca Sports Science Events, $19-20$ June 2020. Alicante, Spain.

JOURNAL OF HUMAN SPORT \& EXERCISE ISSN 1988-5202

(c) Faculty of Education. University of Alicante

doi:10.14198/jhse.2020.15.Proc4.10 


\section{INTRODUCTION}

Motor skills education is an educational process aimed at increasing a pupil's training through body experience and movement. It has a fundamental role for physical development as well as for emotional, relational and intellectual ones.

It enables many and varied experiences individually, with others and with the world of things, also through playing. The motor experience that is proposed within the school curriculum must be as broad as possible; a lack of development may cause both physical and psychological damage.

This article reflects on adapting and transforming physical education via a journey through the circus disciplines, fundamental for the development of the individual, ensuring a unique motor experience. The different circus disciplines increase motor skills, develop dexterity and differentiation of movements (juggling with multiple objects), kinaesthesia and elasticity (skills that can be developed on the trapezius).

We therefore claim that this type of complete motor activity, unique in its kind due to its various disciplines in flight and ground acrobatics, acrobatics, juggling and clowning, can enter the school with dignity also supported by scientific evidence.

The cultural approach towards circus teaching is personal and depends on a person's experience, family education, studies, social, physical and cultural environment: an open teaching, without rigidity, because it always gives space to new variables to evolve and expand its basic motor patterns.

This work reviews the literature on circus pedagogy and the motivations that have led scholars to consider it a valid alternative to be presented in school; effects and results within the Italian school curriculum are analysed.

\section{METHOD}

Our bibliographic research took place through the SPORTDISCUS and EBSCO search engines. The keywords typed were circus, education, physic education, school. The target audience were nursery and primary school pupils. Not all found articles met our requirements, hence were excluded for various reasons, including the fact that they concerned: 1) the education of children within circus companies themselves; 2) the structure of a circus show; 3 ) circus projects in prisons, adult psychiatric communities, etc. This study reviews the literature on circus pedagogy within the school context and the reasons that have led scholars to propose it as a valid alternative for educational institutions: effects, objectives and results within the curriculum are considered. A deep-rooted vision of the school might not consider it right to modify traditional physical education, but it is thanks to the research carried out, despite it being still under development, that we can affirm that circus pedagogy is an excellent variant for the physical education curriculum.

\section{RESULTS}

\section{Educational circus: definition and areas of competence}

The term "circus pedagogy" is used to indicate "a pedagogical area in which children and adolescents are given the opportunity to learn both motor skills and circus skills. The circus area allows young artists to have positive individual and group experiences" (Ammen, 2006, p.30). Circus teaching is part of experiential pedagogy and its tasks include "educational processes and objectives that can be stimulated or achieved 
through their circus training" (Grabowiecki \& Lang, 2007, p. 27) and their specific applications for a target group. According to Grabowiecki and Lang, circus education can be considered as a sub-category of physical education that allows for a wide range of movements and experiences. They consider five pedagogical dimensions:

1. Physical: it includes coordination, strength, dexterity, a sense of rhythm and other physical skills that can be trained through the circus arts.

2. Individual development: it presupposes self-confidence, resistance management that stimulates and supports the processes of spiritual and mental development. Personality is born from this dimension.

3. Social: It encourages social cooperation and interpersonal relationships, including conflicts. Moreover, communicating, cooperating, taking responsibility and developing trust favour team play.

4. Aesthetic-artistic: it promotes creativity in children and young people.

5. Cultural: in which the participants have the opportunity to integrate new possibilities of movement, but also to learn about the circus art (Grabowiecki \& Lang, 2007, p. 27).

Kiphard sees circus education as a learning field through which different sectors of education can be addressed, pedagogical areas that include:

1. Motor pedagogy (teaching of basic psychomotor competencies);

2. Sport pedagogy (teaching of specific technical learning processes);

3. Experiential education (the circus as fascination and adventure);

4. Pedagogy of play (circus role-play and fiction);

5. Social pedagogy (interaction, communication and teamwork).

(Kiphard, 1997, p.15).

Killinger confirms his findings through interviews with people responsible for project design. His research findings refer to the "dimensions of education in the field of circus pedagogy" (Killinger, 2007, p.98). These dimensions are divided into:

1. Motor: the circus arts help to ensure that participants learn to evaluate their body and their abilities.

2. Social: for attention to oneself and the group, developing a sense of responsibility.

3. Emotional: it offers participants the opportunity to transform their feelings into actions, in fact selfresponsibility is important in circus training. Its basis is self-confidence (Killinger, 2007, pp. 100-102).

4. Political, ethical-religious (Killinger, 2007, pp. 100-102).

5. Cognitive: addressed by the promotion of sensory-motor structures. (Killinger, 2007, p. 103).

6. Aesthetical: it allows children to realize their ideas creatively. This occurs mainly through free experimentation of the circus arts, playful discovery and the combination of experiences and new impressions (Killinger, 2007, pp. 105-106).

These were the first empirical results in the field of circus education.

With the awareness that there is no scientific definition of "circomotricity", Casali and Sala affirm: "starting from the definition of psychomotricity in the Devoto-Oli dictionary, we can venture a definition of circomotricity as the construction of a playful path that, by always remaining within the game sphere, relates motor, sensory, cognitive, creative and socialising functions. The founding feature of this path is its setting, which finds its home strictly in the imagination linked to the circus, its characters and its stories"(Casali and Sala, 2018, p. 21). 
The substantial difference between "playing circus" and "doing circus" lies in the real meaning of the two verbs (Ammen, 2006, p.46). In "playing circus" children have the opportunity to play and try out the various artist roles, putting the practice of circus disciplines in the background ("doing circus").

The circus modes of action should not be devalued but serve as a theme for learning the motor elements suitable for various age groups.

The circus arts are in full expansion, especially in education, so much so that many physical education professionals have deepened various studies in this area and revealed that "they are perfectly adaptable to the diversity that exists within the school context, awakening at the same time the playful and symbolic meaning of the circus" (Ontañón and Bortoleto, 2013, p.38).

Learning this discipline takes place in a playful way through "action", "exploration" and "contact" (Casali and Sala, 2018, p.25).

The goal is to expand the areas of experience (bodily, social, relational, cognitive) for a development oriented towards movement and the construction of the personality.

\section{Circus disciplines}

Motor skills, which are used in a laboratory of circomotricity or of circus education, are extremely diverse and subject to constant change. Among the various circus disciplines we find:

Acrobatics: Blume (2007, p.10) describes them with the words "adventure", "art of movement" and "sport". "Adventure" because one has to trust oneself and others, even exposing oneself to risks when performing unusual positions. "Art of movement" formed by the physical structures within the anatomical boundaries of different individuals. "Sport" because it is also control of one's body and development of one's acrobatic skills. We can divide acrobatics into four categories: acrobatics in pairs, pyramids, static trapeze, vertical fabric. Balancing: mastery of balance. When an activity of this type is carried out, it is necessary to "grow" together with the object (Lang, 2007, p.228). The activities taken into consideration are: unicycle, balancing on the wire, Rola-bola.

Juggling: in addition to the classic one with balls, clubs and rings, "other tools are also used such as devil stick, diablo and Kiwidoo" (Christel, 2009, p.45).

According to Bortoleto and Carvalho (2004), the presence of the circus in the educational universe can be justified as relevant content. In fact, one of the "duties of the school is to transmit the culture of the artistic body" (Bortoleto, 2006, p.2).

Clearly any circus activity designed to be carried out in the educational context must adapt its characteristics so that the materials used, the intended objectives and other aspects of its functioning meet the students' needs in safety. The circus pedagogy has specialized and expanded according to the classification of the various motor practices with games that awaken sensations by setting in motion the development of various aspects of human behaviour, such as creativity, cooperation, interculturality, bodily expression, competences and skills (Bortoleto, 2006, pp. 4-5). 
Duprat, Gallardo and Ontañon highlight that these activities are a set of knowledge that can contribute to different objectives of school education, allowing access to a part of the program; an opportunity to live, experiment and discover new forms of expression and knowledge of the body and its possibilities.

In general, we do not have a specific focus but the goals and motor skills vary according to the needs of specific exercises and/or activities. "The fundamental aspect that governs all circus activities is joyfulness. All circus activity is based on creation, stimulation, collaboration, smile, sharing and wonder" (Paci, 2000, p.22). "The cultural aspects that characterize the circus, such as the search for the impossible and the stimulation of the imagination, have strong educational values against the normal, the standardized, the passively accepted and schemes of all kinds. Circus culture has as its objectives: the primary form of nonfinalized motor expression, stimulate the imagination, strike the soul and rejoice together"(Paci, 2000, p.24).

An element not to be overlooked in this context is frustration. "Especially at the beginning, but then in regular practice, one experiences the strong emotion of frustration for not being able to, as well as one's own way of facing and transforming such an emotion" (Zurlo, 2008, p.1). An important concept emerges here, namely "how the social circus can stimulate resilience processes, in which people are led to transform their problems into challenges and their defects into strengths" (Negri, 2015, p.2). Reg Bolton (2004) has developed a model based on six fundamental elements for childhood: commitment, self-realisation and awareness, risk management, trust, dreams, and play. Jackie Davis (2014) adds the "theory of self-determination" to these elements, elaborating four fundamental components for psychological development and well-being: autonomy (being able to choose), competence (feeling capable of achieving goals), belonging (feeling connected to others), intrinsic motivation (to commit, persist and concentrate for the sake of it, without rewards) (Bessone, 2015, p.10).

\section{Cognitive and social learning objectives}

Ballreich describes the connection between thinking and motor skills with a juggling trick: "Here a ball is thrown behind the back, over the shoulder and from one hand to the other. A typical mistake for this throw is that the ball is always thrown too far, the thought that everyone had is to throw, but to get to the goal, the strength and clarity of the movements are lacking" (Ballreich, 2000, p.41). This demonstrates the importance of immediate ball feedback for the thrower. In fact, if "the artist's thought is in harmony with the motor execution of the throw, the throw will be successful" (Ballreich, 2000, p.41). The acquisition of new knowledge is one of the many nuclei of circus pedagogical work, because in addition to learning about a variety of new devices and new forms of movement, each new figure and each new trick must be understood, learned and after that mastered. Furthermore, when "different movement sequences are combined, problem solving skills are required" (Behrens, 2007, p.11).

A good pedagogical circus training should not only teach the techniques, but also stimulate the creation of new movements, figures and tricks autonomously and independently. The teacher can give suggestions and help to master the new tasks and in these situations the pupils' creativity is trained. In this context, planning and exhibition should also be mentioned. "Children are involved in creative processes in which the enhancement of the experience and the confirmation of their uniqueness emerge" (Kohne, 2005, p.157). "Circus pedagogy promotes solidarity and availability, which are obtained through cooperation" (Killinger, 2007, p.99). The circus is a context of "community building since everyone must collaborate in the development and presentation of circus performances" (Engelmann - Pilger, 2007, p.44). In general, motor activities pose particular opportunities for "social learning" (Bahr, 2008, p.7) that Ballreich illustrates in training confidence and reliability in acrobatics. In this context it is also important to develop awareness of dangers and risks. "Children and adolescents, who do not have a precise knowledge of individual limits, risks and 
dangers, can become aware of them and learn to deal with them through circus activity" (Engelmann - Pilger, 2007, p.46). The authors explain the two extremes: very insecure and reserved children who have little selfconfidence, and children who overestimate their abilities and tend to take risky actions. Both can perform stunts by learning how to use their potential appropriately and how to take responsibility for each other.

Zurlo also states that looking at and observing each other causes the motor and postural patterns to be shared and, as Schilder observes, allows one to review and modify any previously acquired, less adequate patterns. "Observing and sharing diversity is an effective strategy to develop the skills in question, to enhance the possibility of accepting the new and the different in oneself" (Zurlo, 2008, p.2).

\section{Effects of circus education}

Ward has often been cited with the CIRCUS classification, providing an image of the learning fields he created:

"C ommunikation (communication)

I mmagination (imagination / fantasy)

$R$ esponsibility (sense of responsibility)

C onzentration (concentration)

U nderstanding (understanding)

S ensitivity (sensitivity)" (Ward, 2000, p.92).

Although the terms listed above may all have justification in the context of circus pedagogy, they appear as sub-categories of items not further defined by Ward.

Killinger describes several fields of learning with the term "circus education"; his dimensions contrast with Ward in a much broader sense and he distinguishes the following categories: "cognitive aspect (think and recognise), aesthetic aspect (aesthetic perception, creativity and judgment), emotional aspect and empathic ability (personal concern, self-confidence, etc.), social aspect, body and motor aspect, practical aspect, ethical-religious aspect, political aspect" (Killinger, 2007, p.30).

If so considered, the error has meant learning through other solutions as there are no movements, evolutions that cannot be integrated into new "exercises" and new possibilities, in circus pedagogy, they contribute to the construction of skills. These involve multiple levels of control regarding motor and postural patterns, development of sense-perceptive abilities.

\section{Circus education within the school curriculum}

Both in the past and in the present, whenever an educational approach occurs in a rigorous but superficial way, we are exposed to an unnecessary risk: promoting a feeling of mistrust and the rejection of these practices (Bortoleto, 2011, p.45). The relation of circus practices with popular culture, the awareness of the body and its expressive potential have made it possible for physical education teachers to consider circus activities as a "possibility to be integrated into the school curriculum" (Bortoleto, 2011, p.49). In order to encourage this young area of study, several educators have demonstrated the richness of diversity of the circus language by offering "a wide range of activities which constitute the typical know-how of a circus show and which can represent knowledge relevant to different educational areas" (Ontañón, de Carvalho, Santos, Tanasovici, Bortoleto, 2019, p.2). The motivation for inclusion in physical education refers not only to the increasing recreational participation of young people in these arts, but also to the awareness that the way these activities are carried out could align well with the objectives present in the physical education curriculum at school. "The circus arts have the potential not only to motivate and engage children in exploring and 
mastering aspects of the physical domain of learning, but also to develop skills beyond the physical" (Price, 2012, p .2).

Cardani emphasizes that we can distinguish the circus as a "renewed" form of motor education (coordination, laterality, balance ...) and as the possibility of appropriating a part of the culture that is not very present in the school routine.

Nursery school

With regard to the body and the movement in Kindergarten, the National Guidelines for the Curriculum (2012), in Italy, tell us that "moving is the first learning factor: searching, playing, discovering, jumping, running to school are a source of well-being and psycho-physical balance"(Annals of Public Education, 2012, p.26). The goals for the development of skills are the following: "children fully live their own corporeity, perceives its communicative and expressive potential, and recognize the signals and rhythms of their own body. They enjoy movement and experiments with postural and motor patterns, apply them in individual and group games, even with the use of small tools, and are able to adapt them to environmental situations inside the school and outdoors. They control the execution of the gesture, assess the risk, interact with others in movement games, in music, in dance, in expressive communication. They recognize their own body, its different parts and represent the body still and in motion" (Annals of Public Education, 2012, p.26).

In the article by Vasquez, Gabellini and De Marco, we recognise objectives and goals that reflect those described. In fact, they affirm that "the circus theme is a great ally of pedagogical planning. The circus content allows for diversified and rich experiences that combine cognitive, emotional and motor components, while also allowing one to stimulate social aspects. Consequently, this strategy contributes to the overall development of the child" (Vasquez, Gabellini and De Marco, 2019, pp.3-4).

In support of this, De Marco states that "the great difference and the great advantage of early childhood education is that it is not segmented, that is, we do not speak of topics, but of disciplinary content and guidelines. In this area there is what we can define as a pedagogical predisposition to carry out interdisciplinary work that brings together all types of games including music, dance, gymnastics, etc." (De Marco, 2016, p.202), in which we can also include the circus arts.

In the "Handbook of Circomotricity" by Casali and Sala, specific for the nursery school, we find accurately described the purposes that circomotricity wants to achieve. "By focusing on the goals that kindergarten tries to promote in children, it emerges: identity, autonomy, skills and citizenship" (Casali and Sala, 2017, p.23). A key ingredient in the circomotricity laboratory is feeling good, without having performance anxiety or competition in the group. "A circomotricity laboratory is one of: creativity, bodily expression, emotional discovery and exploration, putting oneself and one's potential into play, discovering one's abilities, increasing one's bodily and cognitive skills" (Casali and Sala, 2017, p.28). In addition, "circomotricity works on cooperation, on the development of positive group dynamics, on the sense of belonging and on motivation" (Casali and Sala, 2017, pp. 28-29).

"The circus is play" (Casali and Sala, 2017, p.29). For Piaget, "play has a fundamental role in intellectual development: in fact, it stimulates memory, attention, concentration, favours the development of perceptual patterns, the ability to compare, and relationships. A lack of play denounces serious cognitive deficiencies in children" (Casali and Sala, 2017, p.29). 


\section{Primary School}

Motor education is an opportunity to promote cognitive, social, cultural and affective experiences. Through movement, pupils are able to get to know their body and explore space, communicate and relate to others in an adequate and effective way. "The motor experience must be characterized as a positive experience, highlighting pupils' ability to do, making them constantly the protagonist and progressively aware of the motor skills gradually acquired" (Annals of Public Education, 2012, p.76). Taking into consideration its objectives and goals, we can say that circus pedagogy offers pupils "the opportunity to commit to trying and practicing to work on mastering the activity" (Price, 2012, p.3). They also "encourage learning to do" (Price, 2012, p.3). The circus arts have the potential to enhance many key characteristics that teachers hope to see developed in children through physical education: coordination, balance and manipulation skills that are central to many circus activities; determination, perseverance and concentration, necessary to set goals and then achieve and master physical skills, which again can be key characteristics of many challenges. Furthermore, pupils experiment with problem solving by thinking about new ways to achieve their goals, stimulating the imagination to create new solutions. "Circus skills extend psycho-social skills through individual value, with a partner or in a group and through learning from others and with others" (Prince, 2012, p.5).

\section{Example of the impact of circus-based teaching in education}

We have examined a study carried out in Canadian schools (9-12 years old) with the aim of teaching, developing literacy in the circus arts, in physical education. Physical literacy: "competence to perform movement skills, but also the ability, understanding and motivation to let one lead a physically active life" (Kiez, Kriellaars, Cairney, Bortoleto, Dudley, Aubertin, 2019, p.162). This study highlights how the majority of Canadian children do not meet the minimum published guidelines for physical education. Furthermore, attention to sport and traditional forms of athletics can exclude many children from participating "especially if they are unsure of their abilities compared to those of their peers" (Kiez, Kriellaars, Cairney, Bortoleto, Dudley, Aubertin, 2019, p. 163).

The Circus Arts Education (CAI) (Kiez, Kriellaars, Cairney, Bortoleto, Dudley, Aubertin, 2019, p.163) involves the development of movement skills across five families of circus disciplines (acrobatics, manipulation, balance, aerial acrobatics and clownerie) for the artistic expression of individual and/or group movement (Kiez, Kriellaars, Cairney, Bortoleto, Dudley, Aubertin, 2019, p.163).

CAl is fully consistent with physical literacy in the psychological, physical, cognitive and social fields and is an inclusive, non-competitive and safe environment for participants where "everyone is good at something" (Kiez, Kriellaars, Cairney, Bortoleto, Dudley, Aubertin, 2019, p.163).The goal of the CAl is to improve movement skills not only in circus movements, but also in general motor skills (balance, body control, manipulation, locomotion, displacements; social interaction, spatial awareness etc.) (Kiez, Kriellaars, Cairney, Bortoleto, Dudley, Aubertin, 2019, p.163). CAl has great potential for achieving the specific and global learning goals of physical education, in particular, movement, safety, social and personal management and healthy lifestyle practices (Manitoba Education and Training, 2008) (Kiez, Kriellaars, Cairney, Bortoleto, Dudley, Aubertin, 2019, p.163).

The schools that took part in this study were asked to respect and follow the provincial curriculum which provides general and specific learning objectives. This curriculum relates to three general competences:

1. Movement skills (required to perform different skills in different contexts of physical activity);

2. Affective/social skills (necessary to interact with others in different contexts of physical activity);

3. Acquisition of knowledge related to healthy lifestyle practices and the effects of sedentary behaviour (necessary to adopt a healthy lifestyle (Government of Quebec, 2009). 
(Kiez, Kriellaars, Cairney, Bortoleto, Dudley, Aubertin, 2019, p.164).

S-PE schools

S-PE schools used the traditional curricula and teaching methods of sports physical education. For example, the emphasis was placed on the acquisition and practice of specific and fundamental sports skills. The learning, in turn, focused on the improvement techniques to achieve basic competence and its application to the sports context. Lessons were based on the sequence "explain, demonstrate, observe and correct" followed by team games that require using the focus motor skill of the lesson just carried out. Students took physical education classes lasting an average of 68 minutes per class, 3.3 times per week, for a total of 225 minutes (3.75 hours) of physical education per week. All three S-PE schools offered other physical activity opportunities (e.g. after school sports) (Kiez, Kriellaars, Cairney, Bortoleto, Dudley, Aubertin, 2019, p.164).

\section{CAI-PE schools}

The three CAI-PE schools provided a wide range of circus disciplines. The teaching methods used included a pupil-centred focus, using skill progression checklists for all circus skills. The artistic expression of the movement, the technical variations in expression and the choice of progressions aimed at encouraging personal challenges and the appropriation of movement. The teachers had a different circus background. The students of the CAI-PE schools attended the physical education lessons for an average duration of 56.6 min. per class, three times a week, for a total of $169.8 \mathrm{~min}$. (2.83 hours) of physical education per week. However, the performance of CAI (teaching circus arts) within the physical education classes varied from one to three times per week (Kiez, Kriellaars, Cairney, Bortoleto, Dudley, Aubertin, 2019, pp. 164-165).

Physical literacy (PL) was assessed with PLAY (Physical Literacy Assessment for Youth) tools (Kiez, Kriellaars, Cairney, Bortoleto, Dudley, Aubertin, 2019, p.165). The physical literacy assessment tools for young people (PLAY) aimed to improve the physical literacy level of the population. PLAY TOOLS determines gaps in the development of physical literacy and provides calls to action to help improve these areas. Three tools emerged from the set of tools that have been used: PLAY-FUN (assessment of motor competence, knowledge and understanding of 18 movement skills related to the physical education curriculum, assessment made by professionals), PLAY-INVENTORY (a personal evaluative checklist of physical activity participation) and PLAY-SELF (physical literacy self-evaluation) (Kiez, Kriellaars, Cairney, Bortoleto, Dudley, Aubertin, 2019, p.165).

This study showed that children in schools with CAI (teaching circus activity) in physical education class improved their motor skills and, overall, increased their knowledge and understanding, as well as participation in activities, compared to a standard physical education program. The results were consistent with the children's self-assessment. CAI methods seem to provide a quality physical literacy experience in physical education classes that leads to the achievement of curriculum objectives. Overall, CAI (teaching circus activity) can serve as an approach to developing physical literacy that has a significant and substantial benefit for children (Kiez, Kriellaars, Cairney, Bortoleto, Dudley, Aubertin, 2019, pp. 168 -169).

\section{CONCLUSIONS}

The focus of physical education, values and directions seem to agree with the contents of the circus activity. It provides teachers with an interesting and easy to apply insight into the educational experiences they want to offer to children. A wide range of experiences can be explored that help them improve their motor skills, develop dexterity, improve concentration, self-esteem and increase involvement in learning the discipline. 
This is a valid solution precisely because each student can feel free to experiment with interesting and innovative activities within an exercise, since the circus arts are aimed at highlighting the abilities of everyone, not looking at the final result of each single exercise, but enhancing the Person for what one is able to do.

A meeting between physical education and the circus in which the pupils appreciate the playful potential; teachers find new opportunities to improve learning about culture and knowledge of the body and of the circus; schools widen the possibilities of forming critical citizens who are open to various motor disciplines.

Although in the Italian panorama circus pedagogy is still little known and rarely applied within the school curriculum, it represents a valid proposal to bring innovation within contexts that are often still anchored to the traditional teaching model. For a school that today more than ever is involved in processes of transformation, adaptation, review in logistical, technological, instrumental terms, there is a need to strengthen, refine, consolidate targeted pedagogical interventions that can motivate, involve, train, grow at best the younger generations through all the disciplinary knowledge rethought for quantity, quality and originality.

\section{REFERENCES}

Ammen, K. (2006), Abenteuer Zirkus. Zur Bedeutung der Zirkuspädagogik in der Sekundarstufe I [Themenheft]. Zeitschrift für Erlebnispädagogik, 26 (7/8).

Annali della Pubblica Istruzione, (2012), Indicazioni nazionali per il curricolo della Scuola dell'Infanzia e del primo ciclo di istruzione, Le Monnier.

Atti del convegno internazionale "Altro Circo", (2015), Circo sociale: un'altra risorsa.

Bähr I., (2008), Kunststück! Pädagogische Chancen der Bewegungskünste. Bewegungskünste [Themenheft]. Sportpädagogik. 12 (4/5), 4-10.

Ballreich, R. \& Lang, T. (2007), Der pädagogische Wert der Zirkuskünste. In R. Ballreich, T. Lang \& U. von Grabowiecki (Hrsg.). Zirkus spielen. Das Handbuch für Zirkuspädagogik, Artistik und Clownerie (3., komplett überarbeitete und ergänzte Aufl.) (S. 32-58). Stuttgart: Hirzel.

Ballreich, R., (2000), Soziales Lernen in Zirkusprojekten. In S. Schnapp \& W. Zacharias (Hrsg.): Zirkuslust. Zirkus macht stark und ist mehr. Zur kulturpädagogischen Aktualiät der Zirkuspädagogik (S. 32-49). Unna: LKDVerlag.

Behrens, M., (2007), Zirkus als Thema in der Psychomotorik. Statement zum Selbstverständnis der Zirkuspädagogik aus psychomotorischer Perspektive. Praxis der Psychomotorik. 32 (1), 23-25.

Bessone I. (2015), II circo sociale: un 'altra risorsa. Teorie e pratiche delle Arti Circensi al servizio del sociale. Progetto altro circo. Associazione Giocolieri e Dintorni.

Blume, M. (2007), Akrobatik mit Kindern \& Jugendlichen (2. Aufl.). Aachen: Meyer \& Meyer.

Bortoleto M.A.C., (2011), Atividades Circenses: Notas Sobre A Pedagogia Da Educação Corporal E Estética. Cadernos de Formação RBCE, p. 43-55.

Bortoleto M.A.C., (2006), Circo y educación física: los juegos circencenses como recurso pedagógico.

Busse, N. (2007), Der Kinder- und Jugendzirkus als erlebnispädagogischer Lern- und Erfahrungsort. Lüneburg: Edition Erlebnispädagogik.

Cardani L.T., Ontañón T. B, Santos G.R., Bortoleto M.A.C. (2017) Atividades circenses na escola: a prática dos professores da rede municipal de CampinasSP Ciencia e Movimento; 25(4): 128-140.

Casali, Sala (2018), Manuale di circomotricità, Sircus.

Christel, M. (2009), Bewegungskünste. Motorisches Lernen in der Zirkuspädagogik. Norderstedt: Books on Demand $\mathrm{GmbH}$. 
Engelmann-Pilger, N. (2007), Möglichkeiten und Grenzen der Zirkuspädagogik in Bezug auf das Soziale Lernen. Diplomarbeit, evangelische Fachhochschule Berlin.

Grabowiecki, U. von \& Lang, T. (2007), Einradfahren. In R. Ballreich, T. Lang \& U. von Grabowiecki (Hrsg.). Zirkus spielen. Das Handbuch für Zirkuspädagogik, Artistik und Clownerie (3., komplett überarbeitete und ergänzte Aufl.) (S. 244-252). Stuttgart: Hirzel.

Grabowiecki, U. von \& Lang, T. (2007), Jonglieren. In R. Ballreich, T. Lang \& U. von Grabowiecki (Hrsg.). Zirkus spielen. Das Handbuch für Zirkuspädagogik, Artistik und Clownerie (3., komplett überarbeitete und ergänzte Aufl.) (S. 140-156). Stuttgart: Hirzel.

Grabowiecki, U. von \& Lang, T. (2007), Spielerische Partnerakrobatik. In R. Ballreich, T. Lang \& U. von Grabowiecki (Hrsg.). Zirkus spielen. Das Handbuch für Zirkuspädagogik, Artistik und Clownerie (3., komplett überarbeitete und ergänzte Aufl.) (S. 62-90). Stuttgart: Hirzel.

Grabowiecki, U. von \& Lang, T. (2007).1 Zirkuspädagogik im Überblick. In R. Ballreich, T. Lang \& U. von Grabowiecki (Hrsg.). Zirkus spielen. Das Handbuch für Zirkuspädagogik, Artistik und Clownerie (3., komplett überarbeitete und ergänzte Aufl.) (S. 27-30). Stuttgart: Hirzel.

Grabowiecki, U. von (1997), Zirkuspädagogik. Eine schillernde pädagogische Angelegenheit. In. J. W. Ziegenspeck (Hrsg.). Zirkuspädagogik. Grundsätze - Beispiele - Anregungen (S. 30-42). Lüneburg: Edition Erlebnispädagogik.

Grabowiecki, U. von (2007), Pyramiden. In R. Ballreich, T. Lang \&U. von Grabowiecki (Hrsg.). Zirkus spielen. Das Handbuch für Zirkuspädagogik, Artistik und Clownerie (3., komplett überarbeitete und ergänzte Aufl.) (S. 9199). Stuttgart: Hirzel.

Kiez T.K.M, Kriellaars D.J., Cairney J., Bortoleto M.A.C., Dudley D, Aubertin P. (2019), The Impact of Circus Arts Instruction in Physical Education on the Physical Literacy of Children in Grades 4 and 5 , Journal of Teaching in Physical Education, 38, 162-170 https://doi.org/10.1123/jtpe.2018-0269 () 2019 Human Kinetics, Inc. https://doi.org/10.1123/itpe.2018-0269

Killinger, J. (2007), Bildung und Zirkus. Eine Studie anhand von Experteninterviews. Saarbrücken: VDM.

Kiphard, E. (1997), Pädagogische und Therapeutische Aspekte des Zirkusspiels. In J. Ziegenspeck (Hrsg.), Zirkuspädagogik; Grundsätze- Beispiele- Anregungen; Eine Dokumentation anlässlich des Internationalen Kinder-/ Jugend-Circus- \& Theaterfestivals in Hamburg 1997. (S. 14- 19). Lüneburg: Edition Erlebnispädagogik.

Kiphard, E. (2000), Präventive und therapeutische Aspekte der Kinderzirkusarbeit. In Kinder- und Jugendzirkus CABUWAZI e. V. (Hrsg.), Dokumentation des Internationalen Kongresses der Kinderund Jugendzirkusse Berlin 12. bis 14. Juli 2000 und des Internationalen Festivals der Kinder- und Jugendzirkusse Berlin 10. bis 14. Juli 2000 (S. 50-58). Berlin: VAL.

Lang, T. (2007), Keulen- und Poischwingen. In R. Ballreich, T. Lang \& U. von Grabowiecki (Hrsg.). Zirkus spielen. Das Handbuch für Zirkuspädagogik, Artistik und Clownerie (3., komplett überarbeitete und ergänzte Aufl.) (S. 175188). Stuttgart: Hirzel.

Ontañón T. B., de Carvalho D.L., Santos G.R., Tanasovici Cardani Gilson L. Bortoleto M.A.C. (2019), Corpo e arte: uma proposta pedagógica na Educação Física a partir da bola de equilíbrio circense. Educación Física y Ciencia, vol. 21, n² 2, e076, abril-junio. https://doi.org/10.24215/23142561e076

Ontañón, T. B.; Bortoleto, M. A. C.; e Silva, E. (2013), Educación corporal y estética: las actividades circenses como contenido de la educación física. Revista Iberoamericana de Educación, 62, 233243. https://doi.org/10.35362/rie620592

Paci G. (2000), II circo nell'educazione motoria e nell'atletica leggera (p. 20-24).

Price C. (2012), Circus for Schools: Bringing a Circo Arts Dimension to Physical Education Vol. 4, No. 1. Vasques H.C., Gabellini G.S., De Marco A. (2019), O circo na educação infantil: vivências e representações artísticas no desenho, Motrivivência, (Florianópolis), v. 31, n. 60, p. 01-21. https://doi.org/10.5007/2175-8042.2019e60124 
Ward, S. (2000), Pädagogische Wirkungen von Zirkus. In S. Schnapp \& W. Zacharias (Hrsg.): Zirkuslust. Zirkus macht stark und ist mehr. Zur kulturpädagogischen Aktualität der Zirkuspädagogik (S. 92-95). Unna: LKDVerlag.

Zurlo "Contenuti pedagogici di piccolo circo e circo sociale" da "Circoterapia basi teoriche per una metodologia" 2008-2009. 